\title{
Receptor-Mediated cAMP Production in Adult and Infant Ferret Tracheal Epithelium
}

\author{
CAROLYN M. KERCSMAR, YOUNGRAN CHUNG, ${ }^{1}$ AND PAMELA B. DAVIS
}

Department of Pediatrics, Case Western Reserve University at Rainbow Babies and Childrens Hospital, Cleveland, Ohio 44106

\begin{abstract}
Tracheal epithelial cells obtained from adult and infant ferrets were grown in primary culture in vitro. Cells from adult animals grew readily, and many ciliated cells were observed in the cultures. Successful cultures were derived from infant animals, but cell number in infant and adult cultures began to decrease after $6 \mathrm{~d}$. Receptormediated activation of adenylate cyclase was determined by incubating monolayers of adult or neonatal cells with $\beta$ adrenergic agonists, prostaglandin $\mathrm{E}_{2}\left(\mathrm{PGE}_{2}\right)$ and vasoactive intestinal peptide and measuring cAMP production. $\beta$ adrenergic agonists and $\mathrm{PGE}_{2}$, but not vasoactive intestinal peptide, stimulated production of cAMP in both cell types. The $50 \%$ effective concentration for isoproterenol and $\mathrm{PGE}_{2}$ in neonatal ferret tracheal epithelial (NFTE) cells was nearly $\mathbf{1 0}$-fold more than for adult ferret tracheal epithelial (FTE) cells, but maximal agonist-stimulated cAMP production was significantly different between the cell types only for $\mathrm{PGE}_{2}$. Radioligand binding studies were performed using the $\beta$-adrenergic antagonist $\left[{ }^{125}\right.$ I]iodocyanopindolol on membrane particulates from confluent monolayers and freshly isolated FTE cells. Binding of iodocyanopindolol was saturable, stereoselective, and of high affinity (binding affinity $=26.1 \pm 6.6 \mathrm{pmol} / \mathrm{L}$, adult; $16.5 \pm 5.7$ pmol/L, NFTE). Competition studies with the specific $\beta_{2^{-}}$ adrenergic receptor antagonist, ICI 118551 revealed a predominance of $\beta_{2}$-adrenergic receptors on both adult FTE and NFTE cells. Receptor density was significantly higher in adult FTE compared with NFTE cells $(48.2 \pm 9.1,18.1$ $\pm 1.5 \mathrm{fmol} / \mathrm{mg}$, respectively). Basal adenylate cyclase activity was significantly lower in neonatal cells. Functionally coupled receptors for $\beta$-adrenergic agents and $\mathrm{PGE}_{2}$ are present on adult and infant airway epithelium in the ferret. Both the decreased $\beta$-adrenergic receptor number and lower adenylate cyclase activity contribute to the blunted cAMP response of NFTE cells. (Pediatr Res 30: 75-82, 1991)
\end{abstract}

\section{Abbreviations}

DMEM, Dulbecco's minimum essential medium

FTE, ferret tracheal epithelial

HBSS, Hanks' balanced salt solution

IBMX, isobutylmethylxanthine

ICYP, iodocyanopindolol

NFTE, neonatal ferret tracheal epithelial

$\mathrm{PGE}_{2}$, prostaglandin $\mathrm{E}_{2}$

VIP, vasoactive intestinal peptide

Received August 10, 1990; accepted February 22, 1991.

Correspondence: Carolyn M. Kercsmar, M.D., 2101 Adelbert Rd., Rainbow Babies and Childrens Hospital, Pediatric Pulmonology, Cleveland, OH 44106.

Supported by grants R01 HL28386, P01 HL28530, and P30 DK27651 from the National Institutes of Health and grants from the Cystic Fibrosis foundation (Rainbow Chapter).

'Present address: Lutheran General Children's Medical Center, 1775 Dempster St., Park Ridge, IL 60068
$\mathrm{EC}_{50}, 50 \%$ effective concentration

cAMP modulates a multitude of cellular functions in the airways and lung. Cell volume regulation, ion transport, ciliary beat frequency, and mucus secretion are all regulated by intracellular accumulation of cAMP (1-4). In addition, cAMP promotes growth, differentiation, and surfactant release in respiratory epithelial cells $(5,6)$. Many features of the pulmonary maturation that accompany the transition from fetal to extrauterine life are modulated by intracellular cAMP. For instance, both fluid resorption and surfactant production increase in fetal rabbits and lambs treated with $\beta$-adrenergic agonists, agents known to increase intracellular cAMP $(6,7)$.

Developmental changes in cellular regulation and production of cAMP have been reported in a number of experimental animals as well as in humans $(8,9)$. Previous studies used tissues from fetal rabbits, rats, or humans (8-10) for study of developmental changes in airway or whole-lung $\beta$-receptors. However, the lung is a complex structure composed of multiple cell types. To study the ontogeny of airway epithelial cell hormone receptors, we used cultured tracheal epithelial cells isolated from adult and infant ferrets and maintained in vitro. The ferret was chosen because the development of the respiratory epithelium, its progression from a secretory tissue to a largely ciliated epithelium, occurs in a well-defined sequence during the first $28 \mathrm{~d}$ of extrauterine life $(11,12)$. At age $7 \mathrm{~d}$, the tracheal epithelium contains approximately $25 \%$ ciliated cells, $45 \%$ secretory cells, and the remainder basal cells; the adult epithelium contains nearly $60 \%$ ciliated cells and approximately $22 \%$ secretory cells (11). These histologic changes observed in the ferret in the 1st mo of life are comparable with the developmental changes occurring in humans during the last $13 \mathrm{wk}$ of intrauterine life; therefore, the neonatal ferret may be a model for airway epithelial development in premature infants. Furthermore, the ferret is susceptible to infection by human influenza virus, and it develops respiratory histopathologic damage quite similar to that seen in humans, making the ferret an excellent model for study of airway epithelial function after infection and injury.

We undertook this study to determine whether cAMP production in response to physiologic or pharmacologic/therapeutic stimuli changes with development in FTE. Our hypothesis was that receptor-mediated cAMP production differs significantly between infant and adult FTE cells. Primary cultures of tracheal epithelial cells from adult and infant ferrets were used to compare intracellular accumulation of cAMP in response to $\beta$-adrenergic agents, VIP and $\mathrm{PGE}_{2}$. These agents were selected for their known activity in the ferret. $\beta$-Adrenergic receptors have been localized to the respiratory epithelium in the ferret (13). Binding sites for VIP as well as cAMP accumulation and mucus secretion in response to exogenous VIP also occur in the ferret airway but largely in the submucosal glands and much less so in the epithe- 
lium $(14,15)$. When differences in cAMP production between adult and NFTE cells were found, we investigated adenylate cyclase activity as well as the properties of a receptor for which ligands of high sp act are available-the $\beta$-adrenergic receptor. Our results indicate that FTE cells express $\beta$-adrenergic and $\mathrm{PGE}_{2}$ receptors, which are functionally coupled to adenylate cyclase. Exogenous VIP does not stimulate cAMP synthesis in either adult or neonatal airway epithelial cells. In addition, cAMP synthesis is reduced in the infant cells, as is the $\beta$-adrenergic
receptor number.

\section{MATERIALS AND METHODS}

Materials. Antiserum directed against bovine keratin was purchased from Biomedical Technologies, Stoughton, MA; fluorescein-conjugated goat antirabbit antisera was obtained from Cappell, Cooper Biomedical, Malvern, PA. Antibody against cAMP was purchased from Biotek Research, Inc., Lenexa, KS. IBMX, epinephrine, norepinephrine, isoproterenol, and media growth supplements were obtained from Sigma Chemical Co., St. Louis, MO. VIP was purchased from Peninsula Laboratories, Inc., Belmont, CA. $\left[{ }^{125} \mathrm{I}\right] \mathrm{ICYP}$ and $\left[{ }^{125} \mathrm{I}\right] \mathrm{cAMP}$ were obtained from New England Nuclear Corp., Boston, MA. DMEM was purchased from Biofluids, Inc., Rockville, MD, and all other media were obtained from Gibco Labs, Grand Island, NY. FCS was obtained from Hyclone, Logan, UT. ICI 118551 was a generous gift of Imperial Chemical Industries, Cheshire, UK.

Cell culture. Adult ferrets, Mustela putorius furo, of either sex, weighing $0.9-1.6 \mathrm{~kg}$, were housed for 1 to $14 \mathrm{~d}$ before use (Marshall Research Animals, North Rose, NY). The animals were not revaccinated against canine distemper within $2 \mathrm{wk}$ of arrival. Pregnant ferrets arrived 1 wk before due date; infant ferrets were used when they were $7 \mathrm{~d}$ old. These studies were approved by the Case Western Reserve University Committee on Animal Investigation.

The animals were killed by a lethal intraperitoneal injection of pentobarbital, $241 \mu \mathrm{mol} / \mathrm{L}(60 \mathrm{mg} / \mathrm{kg})$, and the tracheas were removed and placed immediately into HBSS containing penicillin, streptomycin, and fungizone. Epithelial cells were isolated by a modification of the method of Wu and Smith (16). Briefly, tracheas were dissected free from overlying connective tissue and washed twice with HBSS. The tracheal lumen was filled with $0.1 \%$ protease (Sigma Type XIV, Sigma Chemical Co.) in DMEM and incubated at $4^{\circ} \mathrm{C}$ for $18 \mathrm{~h}$. The protease solution was collected from the tracheal lumen, and the digestion stopped by the addition of $10 \%$ FCS (Hyclone, Logan, UT). The tracheal lumen was then filled with $10 \mathrm{mM}$ EDTA in DMEM, and the preparation was incubated at $37^{\circ} \mathrm{C}$ for $10 \mathrm{~min}$. The EDTA solution was collected, and the tracheal lumen flushed with 40 $\mathrm{mL}$ of DMEM plus $10 \%$ FCS. All fractions were combined, and the cell suspension was pipetted several times and filtered through 150-mesh Nytex (Tetko, Inc., Elmsford, NY). The cells were centrifuged at $500 \times g$, washed three times with DMEM, resuspended, and counted on a hemacytometer. Cell viability, determined by acridine orange-ethidium bromide staining, was always
greater than $95 \%$.

Culture conditions. Cells were grown in a modification of the medium developed by Groelke et al. (17). Three parts of a 1:1 (vol/vol) mix of DMEM and Ham's F-12 nutrient mixture (Gibco Labs, Grand Island NY) were supplemented with the following: L-glutamine, $2.5 \mu \mathrm{mol} / \mathrm{L}$; penicillin, $100 \mathrm{U} / \mathrm{mL}$; gentamicin, $36.8 \mu \mathrm{mol} / \mathrm{L}(20 \mu \mathrm{g} / \mathrm{mL})$; epidermal growth factor, 3.3 $\mu \mathrm{mol} / \mathrm{L}(20 \mu \mathrm{g} / \mathrm{mL})$; endothelial growth supplement, $811 \mu \mathrm{mol} /$ $\mathrm{L}(30 \mu \mathrm{g} / \mathrm{mL})$; cholera toxin, $0.1 \mathrm{nmol} / \mathrm{L}(10 \mathrm{ng} / \mathrm{mL})$; insulin, $0.83 \mu \mathrm{mol} / \mathrm{L}(5 \mu \mathrm{g} / \mathrm{mL})$; transferrin, $0.06 \mu \mathrm{mol} / \mathrm{L}(5 \mu \mathrm{g} / \mathrm{mL})$; hydrocortisone, $0.05 \mu \mathrm{mol} / \mathrm{L}$; retinoic acid, $1.6 \mathrm{nmol} / \mathrm{L}$; and one part (vol/vol) of fibroblast conditioned medium. Conditioned medium was prepared by incubating confluent monolayers of human fetal lung fibroblasts (GM 5387, NIGMS Human Genetics Mutant Cell Repository, Camden, NJ) in DMEM contain- ing $2 \%$ FCS for $48 \mathrm{~h}$. The medium was removed, filter $(0.22 \mu \mathrm{m})$ sterilized, and frozen at $-20^{\circ} \mathrm{C}$ until it was used. The final concentration of serum in the ferret cell culture medium was $0.5 \%$. Unlike human tracheal epithelial cells, neither FTE nor NFTE cells grew sucessfully in the absence of cholera toxin (18).

The cells were plated at a density of $6 \times 10^{4}$ cells per $\mathrm{cm}^{2}$ in 24- or 48-well $\left(2 \mathrm{~cm}^{2}\right.$ or $1 \mathrm{~cm}^{2}$ growth area, respectively) multiwell plastic tissue culture dishes (Costar, Cambridge, MA) coated with collagen (type I, rat tail or bovine skin) and incubated at $37^{\circ} \mathrm{C}$ in an atmosphere of $5 \% \mathrm{CO}_{2}$ in air. Cell cultures were fed with fresh medium every $48 \mathrm{~h}$.

Aliquots of freshly isolated cells from adult and neonatal tracheas were resuspended at a concentration of $5 \times 10^{4}$ cells/ $\mathrm{mL}$ in HBSS minus calcium and magnesium and used to prepare cytospins. After centrifugation, the cells were fixed in $4 \%$ buffered formalin plus $1 \%$ glutaraldehyde overnight and then stained with $p$-aminosalicylic acid and alcian blue. Differential cell counts were performed under high power; at least 300 cells in four randomly selected fields were counted. Cells were obtained from two separate adult animals and from two pooled litters containing a total of 11 animals.

Cytokeratin immunofluorescent staining. Cells were grown in chamber-slides (Miles Laboratories, Naperville, IL) and used when subconfluent. Medium was removed, and the cells washed three times with Dulbecco's PBS. The cultures were fixed in situ with $3.7 \%$ buffered formalin for $1 \mathrm{~h}$ at room temperature. The formalin was removed, and the cultures washed briefly with PBS. Cells were made permeable with ice-cold methanol for $10 \mathrm{~min}$, washed twice with PBS, and then incubated for $1 \mathrm{~h}$ at $37^{\circ} \mathrm{C}$ with rabbit antiserum directed against bovine keratin. This antiserum recognizes most types ( $A$ and $B$ ) of epithelial keratins, and it does not stain 3T3 cells (19). Control cultures received only normal rabbit serum. The antiserum was removed, the monolayers washed with PBS, and then incubated for $1 \mathrm{~h}$ at $37^{\circ} \mathrm{C}$ with fluorescein-conjugated goat antirabbit antisera. Cultures were washed with and then stored in PBS containing $0.1 \%$ sodium azide until they underwent microscopic examination. Cultures were examined and photographed on a Nikon fluorescence microscope (Nikon Inc., Garden City, NY).

Electron microscopy. Monolayer cultures were fixed in situ with phosphate-buffered $2.5 \%$ glutaraldehyde for $4 \mathrm{~h}$. Specimens were postfixed in $2 \%$ osmium tetroxide and dehydrated in ethanol. The monolayers were lifted from the culture dish with propylene oxide and embedded in Spurr embedding media. Thin sections were cut, stained with uranyl acetate and lead citrate, and examined on a JEM II 100 electron microscope.

cAMP stimulations. Cells were grown in 24- or 48-well plastic dishes and used when confluent (d 4-5) or nearly confluent for NFTE cells. The monolayers were washed once with DMEM at $37^{\circ} \mathrm{C}$ and then incubated for $5 \mathrm{~min}$ with DMEM plus $0.25 \mathrm{mM}$ IBMX. All additional procedures were performed at $37^{\circ} \mathrm{C}$ in room air. Agonists were then added directly to the cultures and incubated for $5 \mathrm{~min}$. The reaction was terminated by aspirating the medium and replacing it with $0.1 \mathrm{~N} \mathrm{HCl}$, which was left in the wells for at least $30 \mathrm{~min}$; previous experiments indicated that the amount of cAMP extracted from the cells was unchanged over an incubation period of $30 \mathrm{~min}$ to $16 \mathrm{~h}$ (data not shown). The acid solution containing the cAMP was removed from the wells and frozen at $-20^{\circ} \mathrm{C}$ until an assay was performed. The cells remaining on the plate were solubilized in $0.1 \mathrm{~N} \mathrm{NaOH}$, and this material was used for the determination of protein by the method of Lowry et al. (20).

cAMP determinations. RIA with acetylated samples was performed, using a modification of the technique described by was 5 to 400 fmol. was 5 to $400 \mathrm{fmol}$. Three external standards were used in each assay; if more than one of the standards was more than 1.67 SD from the mean for that standard, the assay was discarded. Internal standards included with each assay were within $10 \%$ of the
predicted value. 
Membrane preparation. Membrane particulates were prepared from FTE monolayers as previously described (22). Cells were scraped from the plates and pelleted at $500 \times g$ for $10 \mathrm{~min}$; the pellet was resuspended in $10 \mathrm{vol}$ of DMEM and spun again. The pellet was resuspended in $30 \mathrm{~mL}$ of ice-cold buffer $(250 \mathrm{mM}$ sucrose, $5 \mathrm{mM}$ Tris, $5 \mathrm{mM}$ EDTA, $\mathrm{pH}=7.4$ ), incubated on ice for $15 \mathrm{~min}$, and then homogenized using a Polytron (Brinkman Instruments, Westbury, NY) homogenizer, setting 8 , for $15 \mathrm{~s}$. The homogenate was centrifuged at $40000 \times g$ for $10 \mathrm{~min}$ and resuspended in a buffer containing $50 \mathrm{mM}$ Tris and $10 \mathrm{mM}$ $\mathrm{MgCl}_{2}, \mathrm{pH}$ 7.4. The membrane particulates were washed once more by repeating the high-speed centrifugation and resuspension in ice-cold assay buffer. Protein concentration was determined by the method of Lowry et al. (20).

For NFTE cells and freshly isolated adult cells, the procedure was modified as follows. Epithelial cells were prepared from the tracheas of 1-wk-old animals, as described in a previous section. Cells obtained from the tracheas of two or three litters (between seven and 20 animals) were pooled for each experiment. The cells were suspended in culture medium $\left(10^{6}\right.$ cells $\left./ \mathrm{mL}\right)$, placed in a $100-\mathrm{cm}$ glass culture dish (to which minimal cell attachment occurs), and incubated for $16 \mathrm{~h}$ at $37^{\circ} \mathrm{C}, 5 \% \mathrm{CO}_{2}$ in air. Membrane particulates were then prepared as described above.

Binding studies. Saturation isotherms were performed with membrane suspensions ( $50-100 \mu \mathrm{g}$ protein) in assay buffer with [ $\left.{ }^{125} \mathrm{I}\right]-\mathrm{ICYP}, 5$ to $150 \mathrm{pmol} / \mathrm{L}$ with or without $10^{-6} \mathrm{M}$ propranolol at $37^{\circ} \mathrm{C}$ for $90 \mathrm{~min}$. Nonspecific binding was defined as that not displaced by $10^{-6} \mathrm{M}$ propranolol. Kinetic studies were performed using $10 \mathrm{pmol} / \mathrm{L}$ ICYP and incubation times of 0 to $120 \mathrm{~min}$. Bound ligand was separated from free by dilution of the suspension with ice-cold buffer and rapid vacuum filtration onto Whatman GF/C glass fiber filters. After three washes, the filters were dried and counted on an LKB (Pharmacia LKB, Piscataway, NJ) or Packard (Packard Instrument Co., Downers Grove, IL) gamma counter with an efficiency for $\left[{ }^{125} \mathrm{I}\right]$ of $72 \%$. Nonspecific binding was always $<20 \%$ of the total binding under these conditions.

Competition binding studies were performed using 75 to 100 $\mu \mathrm{g}$ membrane protein per sample, $50 \mathrm{pM} \mathrm{ICYP}$, and $10^{-11}$ to $10^{-4} \mathrm{M}$ agonist or antagonist. Stereospecificity was determined by experiments in which ICYP competed for binding site with the $(-)$ and $(+)$ stereoisomers of isoproterenol. Receptor subtypes were quantified by assays in which the specific $\beta_{2}$-antagonist, ICI 118551 , competed for receptor binding sites with ICYP.

Adenylate cyclase assay. The membrane preparation was added to the assay buffer containing $25 \mathrm{mM}$ Tris (pH 7.4), 5 $\mathrm{mM} \mathrm{MgCl} 2,1 \mathrm{mM}$ DTT, and $0.1 \mathrm{mM}$ guanyl-5'yl-imidodiphosphate. The reaction was initiated by addition of $1 \mathrm{mM}$ ATP, and the final incubation volume was $100 \mu \mathrm{L}$ (23). Incubation was for $5 \mathrm{~min}$ at $37^{\circ} \mathrm{C}$. The reaction was terminated by boiling for $3 \mathrm{~min}$. The tubes were allowed to cool to room temperature, and 100 $\mu \mathrm{L}$ of a slurry of alumina were added to each tube. Samples were assayed in triplicate for CAMP as described earlier.

Data analysis. $\mathrm{EC}_{50}$ and $50 \%$ inhibitory concentration were determined from dose-response curves by log-logit plots. Data from binding isotherms for saturation analysis were analyzed according to the method of Scatchard (24). Data from competition experiments were analyzed using the iterative nonlinear curve-fitting program, LIGAND (25). Comparisons of means of two groups were made using a $t$ test for unpaired samples; means of several groups were compared using analysis of variance and Student-Neuman-Keuls multiple comparisons test (26). A $p$ value less than 0.05 was considered statistically significant.

\section{RESULTS}

Cell culture. Tracheal epithelial cells from both adult and neonatal animals grew well on collagen-coated substrates but not on uncoated plastic. Plating efficiency did not differ between adult FTE and NFTE cells $(15.6 \pm 5.1$ versus $11.6 \pm 1.9 \% ; n=$
3 , mean \pm SEM). However, the NFTE cells grew less readily than the adult cells, and their final numbers rarely reached plating density. Cell number began to increase after $48 \mathrm{~h}$ in culture, reached a plateau by $d 5$, and began to decrease after $d 6$ in culture (Fig. 1). Although the doubling time of the adult FTE cells was slightly shorter than that of NFTE cells, it was not statistically significant $(35.2 \pm 6.2 \mathrm{~h}, n=4 ; 56.1 \pm 11.5 \mathrm{~h}, n=$ 3 , mean \pm SEM, respectively). Cultures of adult cells were confluent 4 to $5 \mathrm{~d}$ after plating, when the plating density was as low as $6 \times 10^{4}$ cells $/ \mathrm{cm}^{2}$. NFTE cells reached approximately $60 \%$ confluence by d 5 . Ciliated cells composed $14.8 \pm 1.3 \%$ of the freshly isolated adult FTE cells and $3.7 \pm 0.76 \%$ of the NFTE cell suspensions (mean $\pm \mathrm{SEM}, p<0.0001$ ). Because of the relatively poor growth in vitro, receptor density for NFTE cells was measured only on membranes prepared from freshly isolated cells, which were allowed to recover in culture medium overnight.

FTE cells from adult animals grew as a tightly packed monolayer (Fig. 2). Under phase-contrast microscopy, actively beating adherent ciliated cells were observed for up to $2 \mathrm{wk}$. The cells uniformly stained with FITC-conjugated antikeratin antiserum (Fig. 3). Although $p$-aminosalicylic acid-positive staining material was observed in fixed and stained freshly isolated cells and sections of FTE monolayers, no granules of any type were observed by electron microscopy. Ultrastructural examination of these cells revealed features characteristic of epithelial cells, notably microvilli, junctional complexes, tonofilaments, and cilia (Fig. 4).

NFTE cells appeared larger and had more abundant cytoplasm than adult FTE cells (Fig. 2). Ciliated cells were infrequent $(<2 \%$ of the cells in culture). Essentially all of these cells were also keratin-positive and demonstrated the same ultrastructural features of the adult-derived epithelial cells (Fig. 3, 4).

cAMP production. In the absence of the phosphodiesterase inhibitor, IBMX, the basal cAMP levels in adult FTE cells were greater than those of the NFTE cells (Table 1). In the presence of IBMX, the basal cAMP values were nearly 5-fold higher in the adult FTE cells and 10-fold higher in the NFTE cells, but adult and NFTE cells did not differ (Table 1). Isoproterenol stimulated a dose-related, rapid, sustained increase in intracellular accumulation of cAMP (Fig. 5). For both adult and neonatal FTE cells, the rank order of potency for stimulation of cAMP production was isoproterenol $>$ epinephrine $>$ norepinephrine,

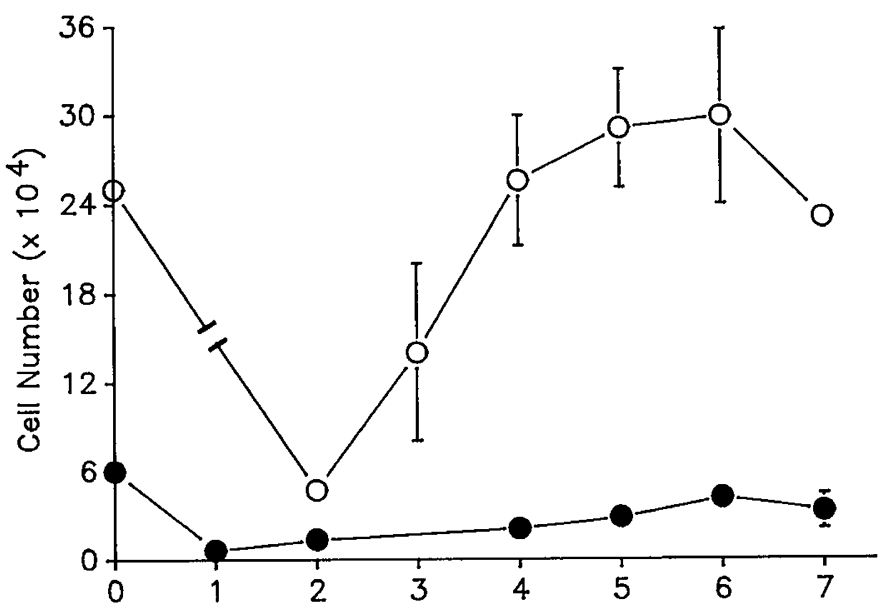

Days in culture

Fig. 1. Growth curves for FTE $(O)$ and NFTE $(\bullet)$ cells. FTE cells grown in 24-well cluster dishes: growth area, $2 \mathrm{~cm}^{2}$, plating density, 12.5 $\times 10^{4} / \mathrm{cm}^{2}$. NFTE cells grown in 48-well cluster dishes: growth area, 1 $\mathrm{cm}^{2}$, plating density, $6.0 \times 10^{4} / \mathrm{cm}^{2}$. Data are means \pm SEM of cell counts performed on cultures from three separate animals (FTE) and three separate pooled litters (NFTE). 


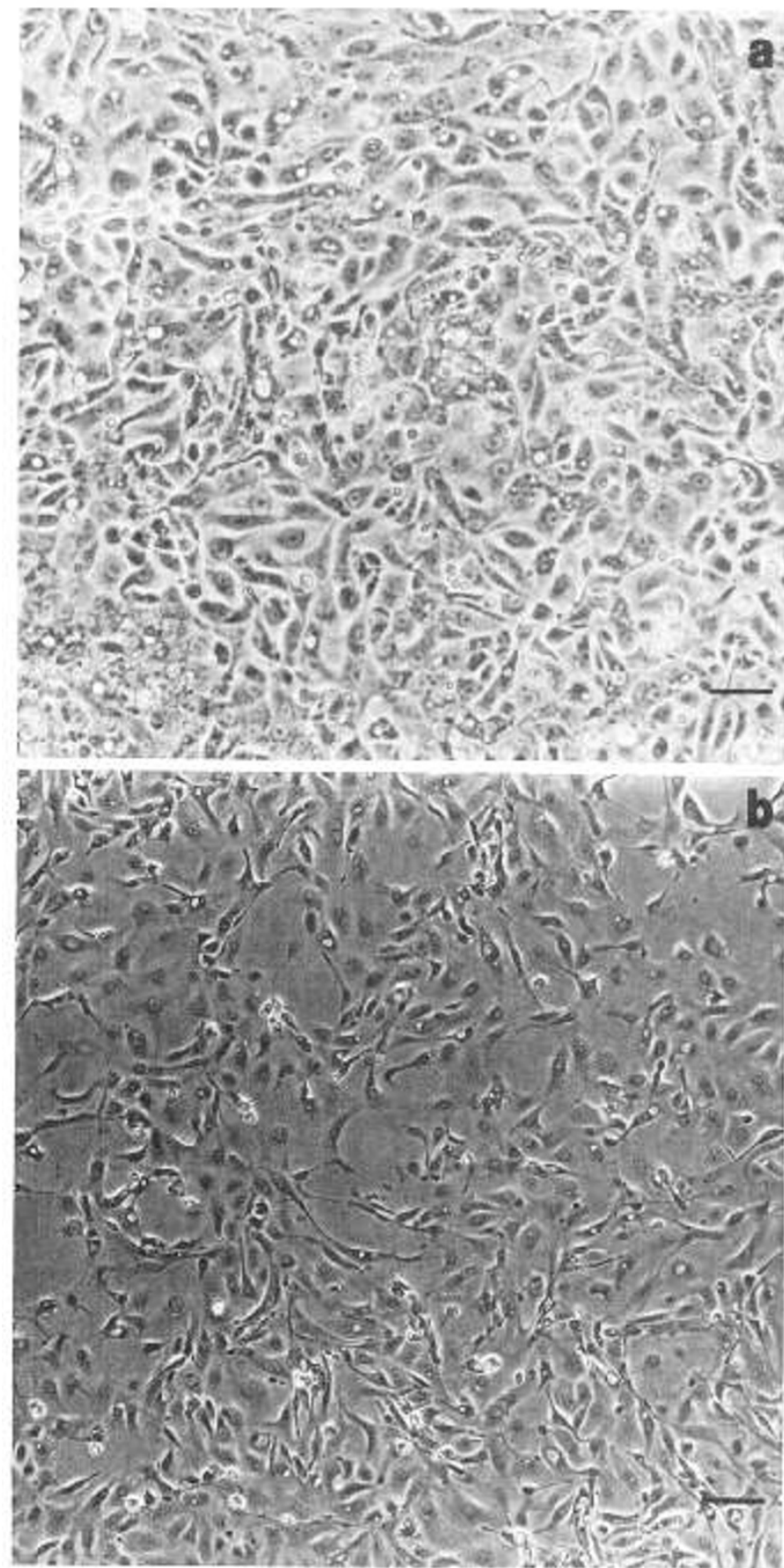

Fig. 2. Phase contrast microscopy of (a) FTE cells at confluence. The field contained numerous ciliated cells. $b$, NFTE cells near confluence. Bar $=2 \mu \mathrm{m}$.

consistent with that expected for a $\beta_{2}$-adrenergic response (Table 2 ). The cAMP response to isoproterenol stimulation was completely abolished by propranolol (adult and neonatal cells) or, in adult cells, by ICI 118551 but not by atenolol (Fig. 6). Although the maximal cAMP levels achieved in NFTE cells were comparable to those seen in adult FTE cells, the $\mathrm{EC}_{50}$ for isoproterenol was 10-fold higher in neonatal cells (Table 2).

Adult FTE and neonatal cells also exhibited increased cAMP production in response to $\mathrm{PGE}_{2}$, in a dose-dependent fashion, but the $\mathrm{EC}_{50}$ was approximately 10 -fold lower for adult cells compared with neonatal cells (Table 2). However, no significant cAMP response to VIP occurred in either adult or neonatal FTE cells: percentages of unstimulated cAMP values were $128.9 \pm$ $16 \%, n=4$; and $91.6 \pm 11 \%, n=3$, respectively.
Adenylate cyclase activity. Adenylate cyclase activity in adult FTE cells, measured in the presence of the nonhydrolyzable GTP analog, guanyl-5' yl-imidodiphosphate and $\mathrm{Mg}^{++}$, was linear with time through $10 \mathrm{~min}$. Basal adenylate cyclase activity was significantly higher in adult FTE cells, as compared with neonatal cells $[160.5 \pm 11.1(n=4)$ and $38.3 \pm 1.6(n=3) \mathrm{fmol} / \mu \mathrm{g}$ protein $/ 5$ min, respectively; mean \pm SEM, $p<0.001]$.

Characterization of $\beta$-adrenergic receptors. Binding of $\left.{ }^{125}\right] \mathrm{I}-$ ICYP to membrane particulates of adult and neonatal FTE cells met criteria for $\beta$-adrenergic receptor binding. It was rapid, saturable, stereoselective, and of high affinity (Fig. 7). The binding of ICYP to its receptor was stereoselective: the $\mathrm{k}_{\mathrm{i}}$ for the (+)isomer of isoproterenol was over 300 -fold higher than (-)isoproterenol $\left(5.4 \times 10^{-5}\right.$ versus $1.4 \times 10^{-7} \mathrm{M}$, respectively). ICYP displayed comparable high affinity for both adult FTE and NFTE cells (Table 3 ). The $\beta$-adrenergic receptor concentration on freshly isolated adult FTE cells was significantly greater than that on NFTE cells (Table 3). Results of ICI 118551 competition binding studies indicated that there was a predominance of $\beta_{2}$ subtype on both the adult and neonatal FTE cells (Table 3, Fig. 8).

\section{DISCUSSION}

The airway mucosa in the newborn ferret is a highly secretory epithelium, although it is devoid of submucosal glands. Submucosal gland development and proliferation of ciliated cells, processes that occur prenatally in humans, are completed during the first $28 \mathrm{~d}$ of postnatal life in the ferret (11). Several physiologic processes occur in the airways in parallel with the changes in mucosal histology. The secreted mucin of the epithelium becomes more acidic, and the rate of mucin and glycoconjugate secretion decreases significantly (11). In addition, after influenza exposure, adult ferret airways do not show extensive involvement and epithelial damage as compared with the infant airway (27). We set out to determine whether these developmental changes in ferret airway epithelium are accompanied by changes in cAMP metabolism. Mucin secretion, ion transport, and ciliary beat frequency are epithelial processes regulated by CAMP, and developmental changes in cellular regulation and production of cAMP have been reported in a number of experimental animals and in humans $(1-4,8,9)$.

The study of cAMP metabolism in airway epithelial cells is facilitated by use of primary cell culture, permitting study of regulation of cellular regulatory processes isolated from the influences of the many other cell types present in the airways. Tracheal epithelial cells from both adult and infant ferrets can be grown successfully in vitro with maintenance of some differentiated and specialized features. Cultures derived from both adults and infants were keratin-positive, had ultrastructural characteristics of epithelial cells, and cultures from adults contained numerous ciliated cells. However, cells obtained from neonatal ferret tracheas grew less readily in vitro, although neither the plating efficiency nor the doubling time differed significantly from adult cells. It is possible that NFTE cells have different requirements for growth factors, nutrients, culture substrate, or they may be dependent on interactions with mesenchymal cells for full growth potential. Ciliated cells were rarely seen in cultures from neonates, reflecting the paucity of ciliated cells in the tracheal epithelium in vivo in 1-wk-old animals. Cultured cells containing mucin granules were not observed in cultures from either adults or neonates, suggesting that culture conditions did not support mucin production or storage in secretory granules.

Adenylate cyclase activity was significantly lower in membranes from NFTE cells than in those from adult cells. This was reflected in the intact cells by lower basal cAMP levels. The basal levels of CAMP measured in both the presence and absence of phosphodiesterase inhibitors are lower in neonatal compared with adult cells; however, the difference in basal values between the cell types is significantly different only in the absence of 

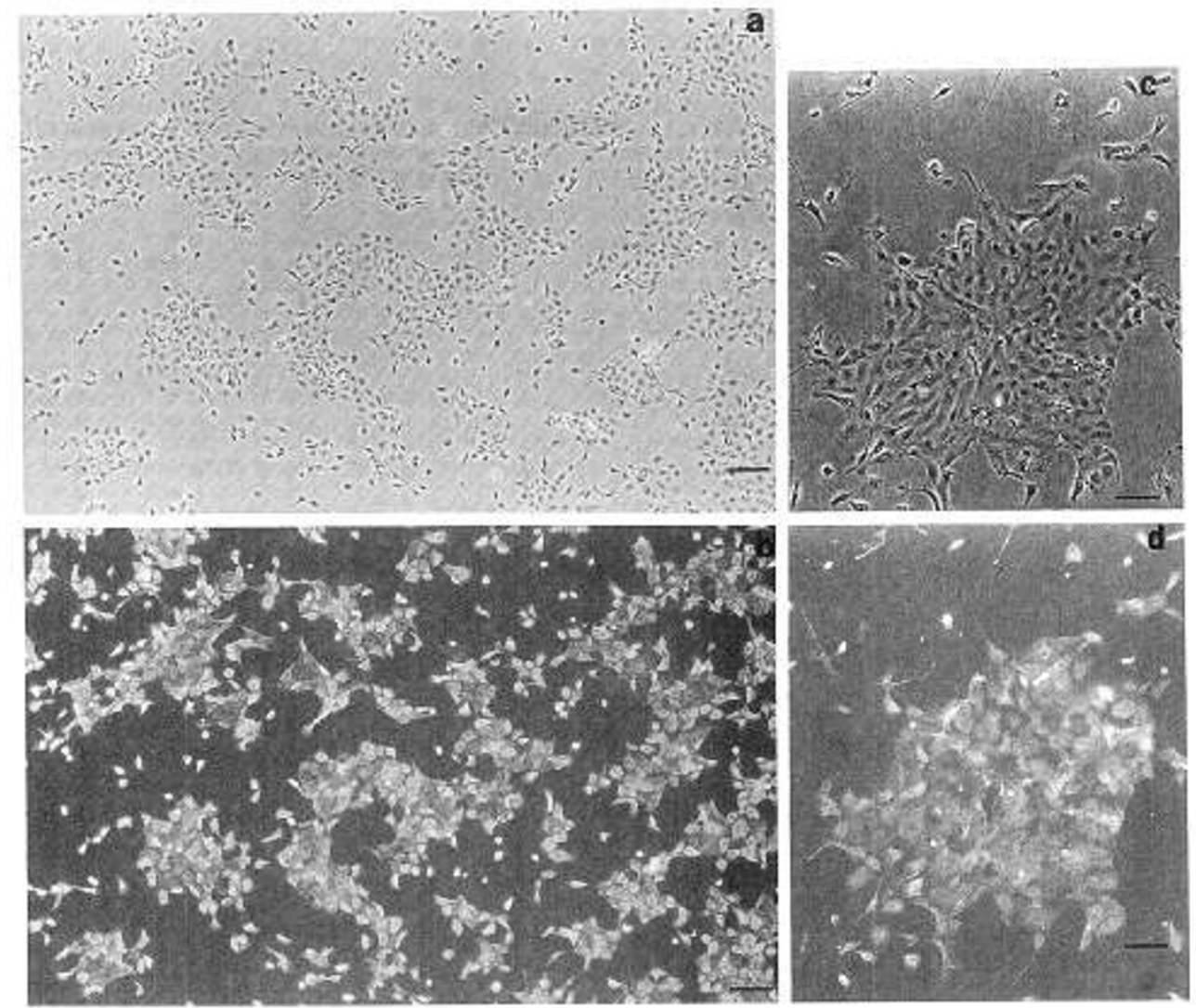

Fig. 3. Fluorescence microscopy of FTE and NFTE cells labeled with antikeratin antiserum and reacted with FITC-conjugated goat antirabbit antiserum. Phase contrast microscopy of FTE $(a)$ and NFTE $(c)$ cells $48 \mathrm{~h}$ after plating. Positive fluorescence of all cells in same fields, $(b)$ FTE and (d) NFTE. No fluorescence was observed in cells exposed to nonimmune rabbit serum. For $a$ and $b, b a r=4 \mu \mathrm{m}$; for $c$ and $d, b a r=2 \mu \mathrm{m}$.

IBMX. Therefore, it is possible that differences in phosphodiesterase concentrations are in part responsible for the differences in cAMP that we observed. Both cultured adult and infant FTE cells responded to $\beta$-adrenergic agonist stimulation with accumulation of cAMP. This response was dose-related, inhibitable by specific antagonist, and showed a rank order of potency consistent with a $\beta_{2}$-adrenergic receptor-mediated response (isoproterenol $>$ epinephrine $>$ norepinephrine). Antagonist studies also indicated a predominantly $\beta_{2}$-adrenergic response. Although there was no significant difference in cAMP production in response to a maximally stimulating concentration of $\beta$-adrenergic agonists, infant-derived cells had a significantly higher $\mathrm{EC}_{50}$ for isoproterenol than adult-derived cells (Tables 1 and 2, Fig. 5) Therefore, physiologic concentrations of catecholamines in the circulation (or low concentrations of exogenous $\beta$-adrenergic agonists) will likely result in lower cAMP production in neonatal airway epithelium than in the adult epithelium. The lower cAMP production in response to adrenergic stimulation in the infant airway may presage age-related differences in physiologic responses, such as ion transport and secretion, but additional studies will be necessary to confirm this.

The pattern of similar cAMP responses to maximal stimulation but higher $\mathrm{EC}_{50}$ suggested that there may be fewer $\beta$ adrenergic receptors on NFTE cells than on adult cells, but there still will be a sufficient number for full adenylate cyclase activation. Indeed, the $\beta$-adrenergic receptor density on NFTE cells is significantly lower but of the same high affinity as that for adult cells (Table 3 ). The relative proportions of $\beta_{1^{-}}$and $\beta_{2}$-receptors are similar in adult and neonatal FTE cells. These data are consistent with findings in other species. $\beta$-Adrenergic receptor density in lung homogenates prepared from fetal rats and rabbits and in tissue sections from rabbits increases with advancing gestational age $(8-10,28,29)$. In humans, the density of functionally coupled $\beta$-adrenergic receptors localized on fetal airway and alveolar epithelia increases during the 2 nd and 3 rd trimesters (9). However, our findings represent the first demonstration of a developmental increase in functionally coupled $\beta$-adrenergic receptors in an isolated lung cell type.

$\mathrm{PGE}_{2}$ also stimulated production of cAMP in both adult and infant FTE cells, although to a lesser degree than isoproterenol, consistent with observations on cAMP production in minced human lung and rabbit and human tracheal epithelial cells ( 9 , 22,30 ). The $\mathrm{EC}_{50}$ for $\mathrm{PGE}_{2}$ was significantly higher in infant FTE cells than adult FTE cells, and the cAMP accumulation achieved at $10^{-5} \mathrm{M} \mathrm{PGE}_{2}$ was less in the infant cells. Although $\mathrm{PGE}_{2}$ receptor concentration could not be directly measured, these data suggested that functional coupling of $\mathrm{PGE}_{2}$ receptors to adenylate cyclase is intact in infant cells and adult.

VIP, a 28 -amino acid peptide that has been localized largely in nerve ganglia as well as submucosal glands, bronchial and pulmonary blood vessels, and epithelium in many mammalian tissues, can interact with specific cell-surface receptors and cause accumulation of intracellular cAMP. Immunocytochemical studies indicated that exogenous VIP increases the cAMP content of submucosal glands of ferret trachea, and functional studies show increased glandular secretion after VIP exposure $(14,15)$. However, little or no accumulation of cAMP occurred in ciliated cells of the FTE in response to VIP (14). In our studies, cAMP did not increase in response to VIP in tracheal epithelial cells from either adult or infant animals. This failure to respond to VIP was not due solely to the absence of any VIP response in ciliated cells alone, because in vivo the infant tracheal epithelium is composed largely of secretory cells and relatively few ciliated cells; also, very few ciliated cells are found in vitro. Our findings on cultured tracheal epithelium were consistent with the immunocytochemical data and support the conclusion that VIP receptors are either absent or not functionally coupled to adenylate cyclase in ferret 

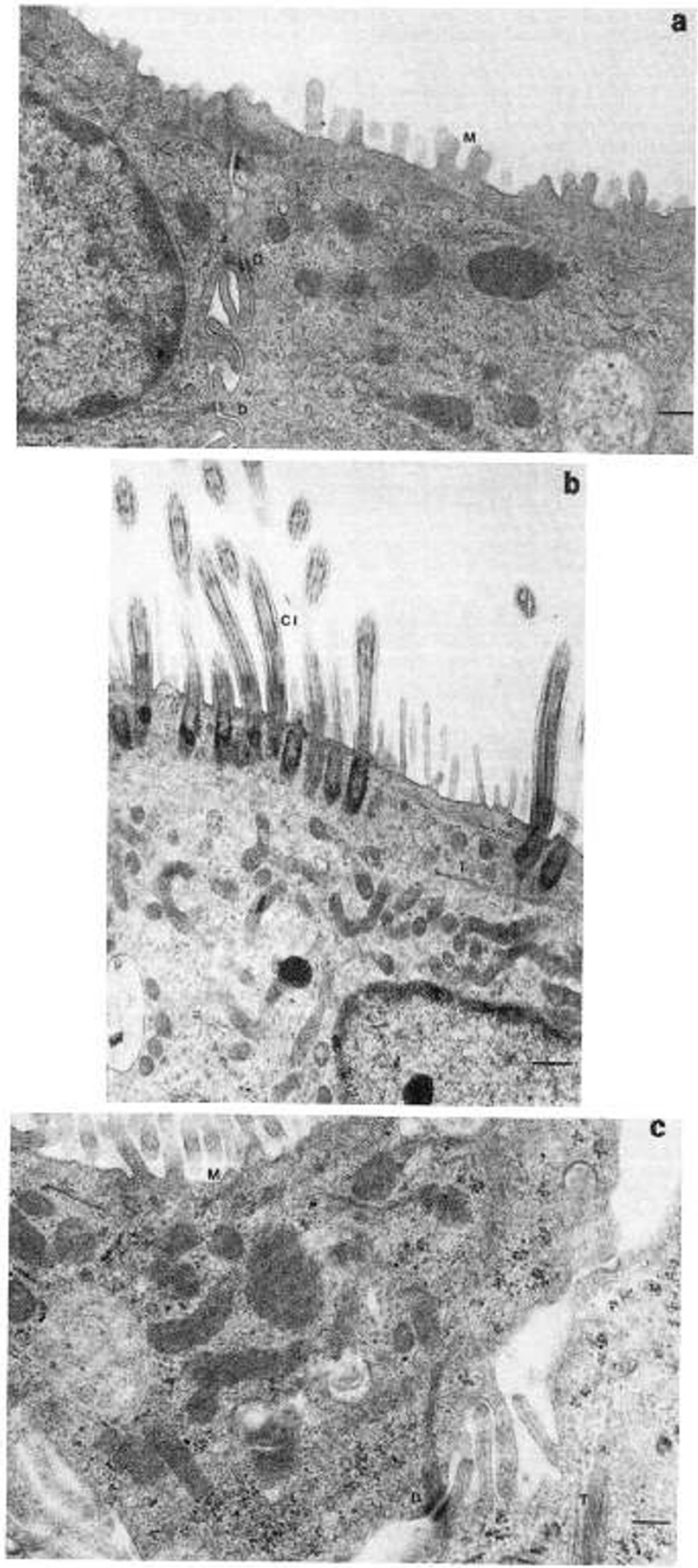

Fig. 4. Electron micrograph of FTE cells in vitro ( $a$ and $b$ ) showing microvilli glycocalx $(M)$, cilia $(C I)$, desmosome $(D)$, and tonofilaments $(T)$. Electron micrograph of NFTE cells in vitro $(c)$ illustrating similar structures but no cilia. For $a$ and $b, b a r=0.25 \mu \mathrm{m}$; for $c$, bar $=0.16 \mu \mathrm{m}$.

airway epithelium. This phenotypic characteristic of ferret airway epithelium in vivo is maintained in vitro in our culture system.

The changes we observed in adenylate cyclase, $\beta$-adrenergic receptor concentration, and CAMP production in response to $\mathrm{PGE}_{2}$ in adult FTE and NFTE cells could reflect differences in cell composition (percentage of ciliated versus nonciliated cells), the ontogeny of the receptors on their respective cell types, or a
Table 1. Agonist-stimulated cAMP production by adult and neonatal FTE cells*

cAMP

( $\mathrm{fmol} / \mu \mathrm{g}$ protein)

\begin{tabular}{lcc}
\cline { 2 - 3 } \multicolumn{1}{c}{ Stimulus } & Adult & Infant \\
\hline None, no IBMX & $83.4 \pm 10.5$ & $24.8 \pm 5.1 \dagger$ \\
& $(n=4)$ & $(n=3)$ \\
None & $411.1 \pm 55.2$ & $292.1 \pm 73.7$ \\
& $(n=13)$ & $(n=4)$ \\
Iso $\left(10^{-5} \mathrm{M}\right)$ & $2021.7 \pm 142$ & $1368.9 \pm 384.2$ \\
& $(n=8)$ & $(n=3)$ \\
PGE $_{2}\left(10^{-5} \mathrm{M}\right)$ & $833.3 \pm 42.3$ & $339.9 \pm 87.9 \dagger \ddagger$ \\
& $(n=3)$ & $(n=2)$ \\
Forskolin $\left(10^{-4} \mathrm{M}\right)$ & $1958.5 \pm 189.9$ & $2285.1 \pm 594$ \\
& $(n=4)$ & $(n=4)$ \\
\hline
\end{tabular}

* Values are means \pm SEM. Unless otherwise noted, all incubations were performed in the presence of $0.25 \mathrm{mM}$ IBMX. Iso, isoproterenol. $\dagger p<0.05$, compared to adult.

$\$$ Mean of duplicate measures made on two separate occasions, each using cells obtained from 12 animals from two litters.

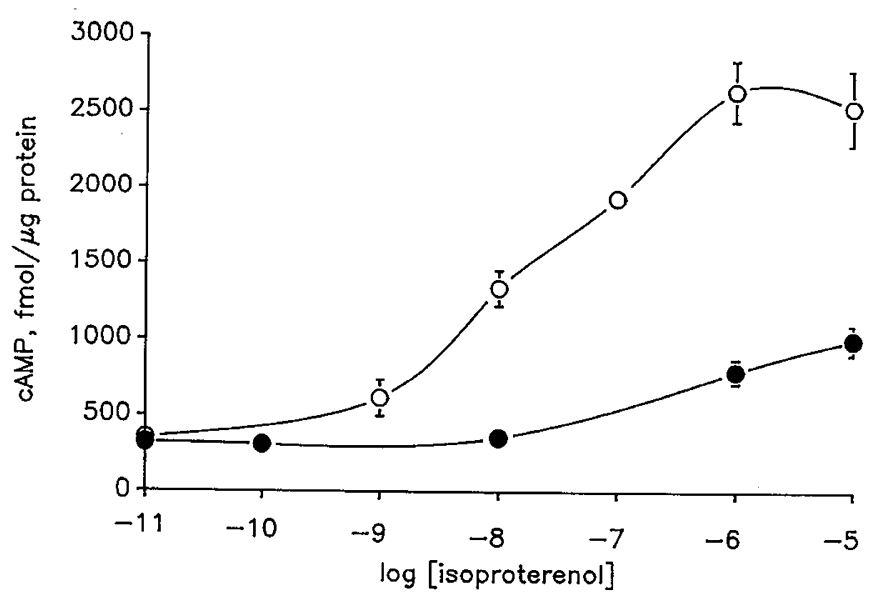

Fig. 5. Dose-response curves for isoproterenol in (O) FTE and (๑) NFTE cells. Data are means of duplicate measurements from two pooled litters $(n=20)$, NFTE, and three separate adult animals, FTE. Basal values are $293.1 \pm 35.5 \mathrm{fmol} / \mu \mathrm{g} \mathrm{NFTE}$ and $494 \pm 96.3 \mathrm{fmol} / \mu \mathrm{g}$ FTE; mean \pm SEM in the presence of IBMX.

Table 2. Sensitivity of FTE adenylate cyclase system to agonists*

\begin{tabular}{lcc}
\hline & \multicolumn{2}{c}{$\mathrm{EC}_{50}(\mathrm{nM})$} \\
\cline { 2 - 3 } \multicolumn{1}{c}{ Agonist } & Adult & Neonate \\
\hline Iso & $12.4 \pm 4.2$ & $243 \pm 37 \dagger$ \\
& $(n=8)$ & $(n=4)$ \\
PGE $_{2}$ & $46.6 \pm 2.3$ & $573 \pm 160 \neq$ \\
& $(n=3)$ & $(n=3)$ \\
Epinephrine & $22.2 \pm 5.4$ & $358 \S$ \\
& $(n=3)$ & \\
Norepinephrine & $136 \pm 10$ & $5840 \S$ \\
& $(n=2)$ & \\
\hline
\end{tabular}

$*$ Values are means \pm SEM. Iso, isoproterenol.

$\dagger p<0.01$, compared to adult.

$\ddagger p<0.05$, compared to adult.

$\S$ Mean of duplicate measures made on two separate occasions, each using cells obtained from 11 animals from two litters.

consequence of the culture system. It is unlikely that the findings are entirely due to the culture conditions, because data on receptor concentration and cAMP responses are quite similar in both freshly isolated and cultured cells. Ciliated and nonciliated cells could differ in receptor complement and responses, but 


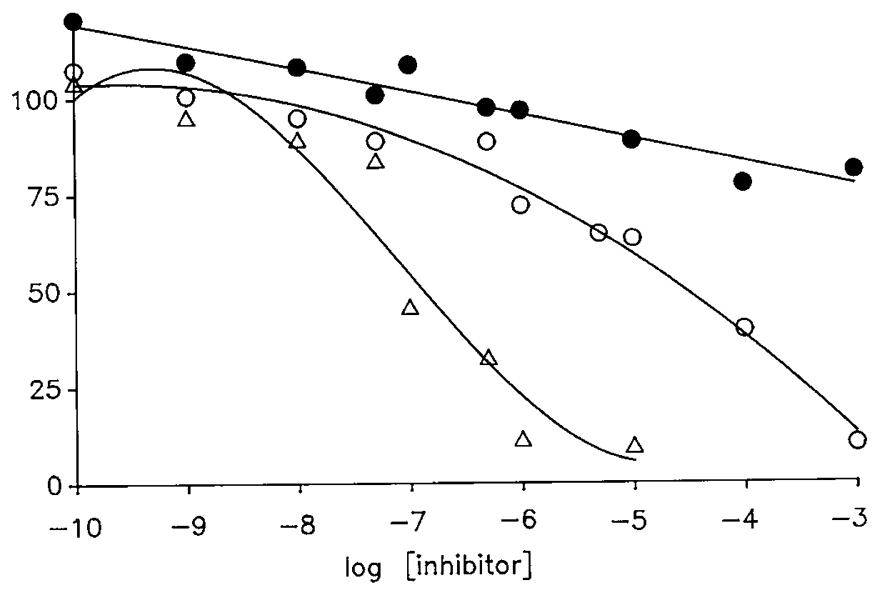

Fig. 6. Inhibition of isoproterenol stimulated $\left(10^{-5} \mathrm{M}\right)$ cAMP production in FTE cells by ICI $118551(\mathrm{O})$, atenolol $(\bullet)$, and propranolo $(\triangle)$. Data are means of triplicate measurements made on cells from a single animal and are representative of two other experiments.

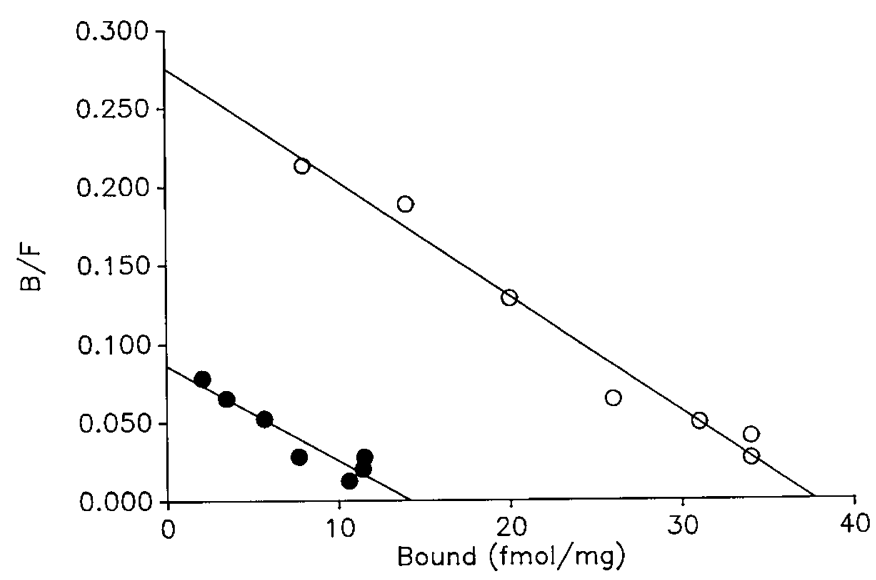

Fig. 7. Scatchard plots of [ $\left.{ }^{125}\right] \mathrm{I}-\mathrm{ICY}$ P binding to FTE $(O)$ and NFTE (๑) cells. Data are means of duplicate measurements from a single adult animal and three pooled litters of neonates. Three other experiments gave the same results.

Table 3. $\beta$-Adrenergic receptor properties: adult and neonatal FTE cells*

\begin{tabular}{lcc}
\hline & Infant & Adult \\
\hline $\mathrm{Bmax}(\mathrm{fmol} / \mathrm{mg})$ & $18.1 \pm 1.5 \dagger$ & $48.2 \pm 9.1$ \\
& $(n=6)$ & $(n=6)$ \\
$\mathrm{k}_{\mathrm{d}}(\mathrm{pmol} / \mathrm{L})$ & $16.5 \pm 5.7$ & $26.1 \pm 6.6$ \\
& $(n=3)$ & $(n=3)$ \\
$\% \beta_{2}$ & $69 \pm 5.5$ & $79.6 \pm 5.8$ \\
& $(n=3)$ & $(n=3)$ \\
\hline
\end{tabular}

$*$ Values are means \pm SEM. Bmax, maximum binding.

$\dagger p<0.05$, compared to adult.

better means of separating the various cell types that exist in the respiratory epithelium would be necessary to explore this possibility.

Our data indicate that ontogenic changes occur in freshly isolated and FTE cells placed in primary culture, in both the adenylate cyclase itself and in some of the receptors that regulate it. These findings suggest that in neonatal ferret airway epithelium the ability to increase cAMP in response to physiologic concentrations of endogenous hormones, such as epinephrine and $\mathrm{PGE}_{2}$, is poor; those elements of epithelial function that are closely governed by cAMP - secretion, ciliary beat frequency, ion transport-may not be regulated well in infants. Changes in these regulatory elements with development may improve the
\% Bound

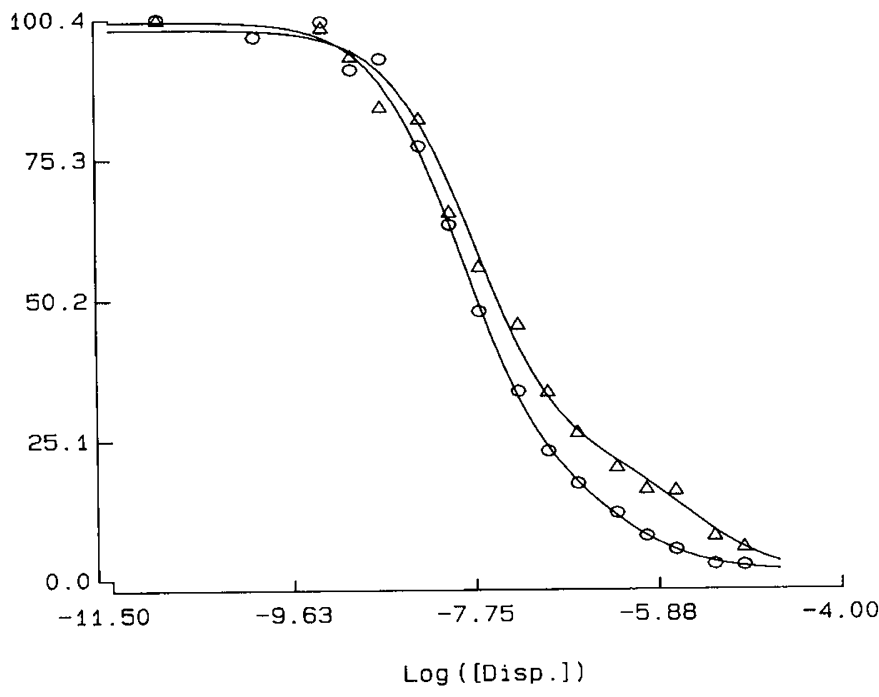

Fig. 8. Competition of ICI 118551 with [ $\left.{ }^{125}\right]$ I-ICYP. O, FTE cells; $\triangle$, NFTE cells. Data points are means of duplicate measures made on cell membranes isolated from cells from a single adult animal and from three pooled litters of neonates. Two other experiments gave the same results.

organism's ability to respond in a more appropriate and adaptive fashion to physiologic or environmental challenge.

Acknowledgments. The authors thank Yoshie Hervey and Catherine Silski for expert technical assistance, Dr. Thomas Massella for performing electron microscopy, and Beth Peticca and Karen Toil for typing the manuscript.

\section{REFERENCES}

1. Eling TE, Danilowicz RM, Henke DC, Sivarajak K, Yankaskas JR, Boucher RC 1986 Arachidonic acid metabolism by canine tracheal epithelial cells: product formation and relationship to chloride secretion. $J$ Biol Chem 261:1284-1289

2. Lazarus SC, Basbaum CB, Gold WM 1984 Localization of cAMP in dog and cat trachea: effects of $\beta$-adrenergic agonists. Am J Physiol 247:C327-C334

3. Klinger JD, Tandler B, Liedtke CM, Boat TF 1984 Proteinases of Pseudomonas aeruginosa evoke mucin release by tracheal epithelium. J Clin Invest 4:16691678

4. Camner PK, Standberg K, Philipson K 1976 Increased mucociliary transport by adrenergic stimulation. Arch Environ Health 31:79-82

5. Wiley JC Laveck MA McClendon IA, Lechner JF 1985 Relationship of ornithine decarboxylase activity and CAMP metabolism to proliferation of normal bronchial epithelial cells. J Cell Physiol 124:207-212

6. Walters DV, Olver RE 1978 The role of catecholamines in lung liquid absorption at birth. Pediatr Res 12:239-242

7. Ekelund L, Burgoyne K, Enhorning G 1983 Pulmonary surfactant release in fetal rabbits: immediate and delayed response to terbutaline. Am J Obstet Gynecol 147:437-443

8. Whitsett JA, Darovec-Beckerman C, Rice WR 1983 Ontogeny of adenylate cyclase activity in the rat lung: guanine nucleotides and cytosolic factors. Pediatr Res 17:553-56

9. Davis DJ, Dattel BJ, Ballard PL, Roberts JM $1987 \beta$-adrenergic receptors and cyclic adenosine monophosphate generation in human fetal lung. Pediatr Res 21:142-147

10. Whitsett JA, Machulskis A, Noguchi A, Burdsall JA 1982 Ontogeny of $\alpha_{1}$ and $\beta$-adrenergic receptors in rat lung. Life Sci 30:139-145

11. Leigh MW, Grambling TM, Carson JL, Collier AM, Wood RE, Boat TF 1986 Postnatal development of tracheal surface epithelium and submucosal glands in the ferret. Exp Lung Res 10:153-169

12. Robinson NP, Venning L, Kyle H, Widdicombe JG 1986 Quantitation of the secretory cells of the ferret. J Anat 145:173-188

13. Barnes PJ, Basbaum CB, Nadel JA, Roberts JM 1982 Localization of $\beta$ adrenoreceptors in mammalian lung by autoradiography. Nature 299:444447

14. Lazarus SC, Basbaum CB, Barnes PJ, Gold WM 1986 cAMP immunocytochemistry provides evidence for functional VIP receptors in trachea. Am J Physiol 251:C115-C119

15. Peatfield AC, Barnes PJ, Bratcher C, Nadel JA, Davis B 1983 Vasoactive intestinal peptide stimulates tracheal submucosal gland secretion in ferret. Am Rev Respir Dis 128:89-93 
16. Wu R, Smith D 1982 Continuous multiplication of rabbit tracheal epithelial cells in a defined, hormone-supplemented medium. In Vitro 18:800-812

17. Groelke JW, Coalson JJ, Baseman JB 1985 Growth requirements of ferret tracheal epithelial cells im primary culture. Proc Soc Exp Biol Med 179:309317

18. Kercsmar CM, Infeld MD, Silski CL, Davis PB 1990 Adenosine 3:5' cyclic monophosphate synthesis by human tracheal epithelial cells. Am J Respir Cell Mol Biol 2:33-39

19. Chopra PP, Sullivan J, Wille JJ, Siddiqui KM 1987 Propagation of differentiating normal human tracheobronchial epithelial cells in serum-free medium. J Cell Physiol 130:173-181

20. Lowry OH, Rosebrough NS, Farr AL, Randall RJ 1951 Protein measurement with the folin phenol reagent. J Biol Chem 193:265-275

21. Harper JF, Brooker G 1975 Femtomole sensitive radioimmunoassay for cAMP and cGMP after $2^{\prime}-0$-acetylation by acetic anhydride in aqueous solution. $J$ Cyclic Nucleotide Res 1:207-218

22. Davis PB, Silski CL, Kercsmar CM, Infeld M $1990 \beta$-adrenergic receptors on human tracheal epithelial cells in primary culture. Am J Physiol 258:C71C76

23. Davis PB, Laundon SC 1980 Adenylate cyclase in leukocytes from patients with cystic fibrosis. J Lab Clin Med 96:75-84

24. Scatchard $G 1949$ The attraction of proteins for small molecules and ions. Ann NY Acad Sci 51:660-672

25. Munson PJ, Rodbard D 1980 LIGAND: a versatile computerized approach for characterization of ligand-binding systems. Anal Biochem

26. Glantz SA 1987 Primer of Biostatistics. McGraw-Hill, New York, pp 64-98

27. Smith H, Sweet C 1988 Lessons for human influenza from pathogenicity studies with ferrets. Rev Infect Dis 10:56-75

28. Gatto C, Johnson MG, Seybold V, Kulik TJ, Lock JE, Johnson DE 1984 Distribution and quantitative developmental changes on guinea pig pulmonary $\beta$-receptors. J Appl Physiol 57:1901-1907

29. Barnes P, Jacobs M, Roberts JM 1984 Glucocorticoids preferentially increase fetal alveolar $\beta$-adrenoreceptors: autoradiographic evidence. Pediatr 18:1191-1194

30. Liedtke CM 1988 Differentiated properties of rabbit tracheal epithelial cells in primary culture. Am J Physiol 225:C760-C770 